\title{
Kajian Formulasi Bacillus thuringiensis Dengan Carrier Limbah Cair Pabrik Kelapa Sawit Untuk Pengendalian Ulat Api (Setora nitens)
}

\author{
DOI 10.18196/pt.2015.036.24-30
}

\author{
Dwi Wahyuono \\ PT. Astra Agro Lestari, Kawasan Industri Pulogudang,
}

Blok OR. 1-2, Pulo Ayang Raya, Rw. 9, Jatinegara, Cakung, Kota Jakarta Timur, Daerah Khusus Ibukota, Jakarta 13920, Indonesia, e-mail:d.wahyuono@gmail.com

\begin{abstract}
ABSTRAK
Penelitian ini bertujuan untuk mengkaji berbagai formulasi media Carrier Limbah Air Kelapa Sawit untuk B. thuringiensis dan mengetahui efektifitas berbagai formulasi B. thuringiensis pada Carrier limbah cair pabrik kelapa sawit (LCPKS) untuk pengendalian Ulat Api. Penelitian telah dilaksanakan pada bulan April hingga Desember 2013 menggunaan rancangan acak lengkap satu faktor yang disusun dalam Rancangan Acak Lengkap (RAL). Penelitian ini terdiri dari dua tahap yaitu pengembangan B. thuringiensis pada media limbah cair pabrik kelapa sawit, dilanjutkan tahap pengujian bioassay. Tahap satu terdiri dari 4 formulasi yaitu LCPKS 100\%, LCPKS 75\%, LCPKS 50\%, dan media LB cair sebagai Kontrol positif. Setiap formula LCPKS ditambahkan dengan gula merah 0.4 g, 30 ml air kelapa dan diinokulasikan dengan B. thuringiensis. Pada pengujian bioassay setiap formula diujjkan pada Setora nitens, selain itu ditambahkan perlakuan kontrol yang berisi air steril. Parameter yang digunakan terdiri penghitungan jumlah bakteri B. thuringiensis, mortalitas (\%), kecepatan kematian (ekor/hari), perubahan persentase populasi (\%) dan hambatan makan (\%). Media alternatif Limbah Cair Pabrik Kelapa Sawit dapat digunakan sebagai media pengembangan $B$. thuringiensis dengan jumlah spora 7,6 x $10^{7} \mathrm{CFU} / \mathrm{ml}$. waktu inkubasi optimal dengan kandungan senyawa aktif tertinggi yaitu pada masa inkubasi 48 jam. Penggunaan media alternatif LCPKS 100\% + 0,4 g gula merah + 30 ml air kelapa + B. thuringiensis memberikan hasil terbaik sebagai bioinsektisida hayati karena memiliki nilai mortalitas, perubahan persentase populasi, waktu kematian dan hambatan makan yang paling tinggi.
\end{abstract}

Kata kunci: Media alternatif, B. thuringiensis, Bioassay

\begin{abstract}
This research aims to examine palm oil effluent as a carrier for B. thuringiensis and its effectiveness against setora nitens instar II-III in palm plantation. This research was held on April - December 2013 using single factor experiment method that has been arranging in completely randomized design (CRD). The research have two stages, first stage: development of B. thuringiensis and second stage: testing bioassay. First stage consist of three treatments that is 100\%, 75\%, 50\% of Palm Oil Effluent and Luria Bertani Broth as a possitive control. Every treatment was added 0,4 g red sugar and 30 ml coconut water. the treatment in second stage same with first stage but use destilled water in addition treatment. The parameter used are viability of B. thuringiensis, mortality (\%), the speed of mortality, the change of population (\%), and anti feedant (\%). The result shown that palm oil effluent serve the purpose of alternative media of development $B$. Thuringiensis $7,6 \times 10^{7} \mathrm{CFU} / \mathrm{ml}$. The optimal incubation period based of the toxcicity that is 48 hours. Formulation LCPKS 100\% + 0,4 g red sugar + $30 \mathrm{ml}$ coconut water $+B$. thuringiensis inclined more better based on the parameter of mortality, the change of population precentage, the speed of mortality amd anti feedant.

Keywords: Alternative media, B. thuringiensis, Bioassay
\end{abstract}

\section{PENDAHULUAN}

Perkebunan Kelapa Sawit (Elaeis guinensis Jack) adalah industri yang penting dan strategis bagi negara Indonesia, komoditas kelapa sawit dari perkebunan merupakan kontributor penerimaan devisa negara yang dapat diandalkan. Hal ini dapat dilihat dari nilai ekspor produk kelapa sawit pada tahun 2009 mencapai US\$ 11. 605.431 dan pada tahun 2010 mengalami peningkatan menjadi US\$12.626.595 dengan volume sebanyak 20. 615.958 ton CPO (Ditjenbun, 2011).

Tanaman kelapa sawit yang diusahakan secara monokultur meliputi hamparan yang luas, sangat rawan terhadap serangan hama. Stabilitas iklim dan tersedianya makanan yang berkesinambungan dengan mutu yang baik, merupakan faktor laju perkembangan populasi hama (Sipayung dan Hutahuruk, 1982). Salah satu penyebab renda- 
hnya produksi kelapa sawit di Indonesia adalah gangguan hama dan penyakit. Ulat pemakan daun kelapa sawit (UPDKS) yang utama dan sering menimbulkan kerugian adalah Ulat Api (Setora nitens) umumnya diatasi dengan menggunakan insektisida kimia sintetik yang mampu menurunkan populasi hama dengan cepat, penerapan sistem pengendalian hama terpadu (PHT) terhadap UPDKS dengan mengoptimalkan pelestarian dan pemanfaatan agensia hayati yang ada di dalam ekosistem kelapa sawit terbukti dapat mengatasi masalah tersebut. Pengendalian hayati ulat api pada kelapa sawit dapat menggunakan mikroorganisme entomopatogenik, yaitu bakteri Bacillus thuringiensis (Sipayung dan Hutauruk, 1982). Hingga saat ini insektisida berbahan aktif $B$. thuringiensis seperti Delfin WDG dan Thuricide HP sering digunakan di perkebunan kelapa sawit untuk mengendalikan ulat api (S. nitens). Namun kenyataannya dalam aplikasi dilapangan, penggunaan produk $B$. thuringiensis komersial memerlukan biaya yang mahal. Oleh sebab itu perlu dicari suatu alternatif formulasi carrier yang murah dan efektif yang dapat dijadikan sebagai medium pertumbuhan $B$. thuringiensis dengan harga yang lebih murah, dengan produksi spora $B$. thuringiensis yang tinggi. Medium alternatif yang mudah dan murah yaitu dengan menggunakan limbah cair pabrik kelapa sawit.

B. thuringiensis dapat dikembangkan dengan berbagai media padat atau media cair. Syarat medium yaitu mengandung zat makanan yang mudah digunakan untuk mikrobia, memiliki tekanan osmosis yang sesuai, tidak mengandung zat-zat penghambat, memiliki $\mathrm{pH}$ yang sesuai untuk pertumbuhan mikrobia dan steril. Kebanyakan bakteri membutuhkan zat-zat seperti karbohidrat, protein, dan lemak (Dwidjoseputro, 1989). Limbah cair pabrik kelapa sawit mempu- nyai kandungan nutrisi, dan komponen lainnya dengan kadar relatif tinggi (Loekito, 2002). Dengan kandungan nutrisi tersebut maka limbah cair pabrik Kelapa Sawit mempunyai potensi sebagai medium untuk memproduksi spora $B$. thuringiensis. Hasil penelitian Dwiyantores dkk (2012) menunjukkan penggunaan media alternatif pupuk organik cair $200 \mathrm{ml}+0,4$ g gula merah + 0,6 g Urea dapat meningkatkan nilai mortalitas lebih tinggi yakni 93,33\%, pengurangan persentase populasi lebih cepat yakni, 6,67\% dan hambatan makanan 22\% dalam waktu lima hari. Dengan demikian alternatif carrier yang dapat digunakan adalah pemanfaatan limbah cair pabrik kelapa sawit serta penambahan air kelapa dan gula merah sebagai sumber karbohidrat dan vitamin perlu dilakukan.

Tujuan dari penelitian ini adalah untuk mengkaji berbagai formulasi media carrier limbah air kelapa sawit untuk B. thuringiensis dan mengetahui efektifitas berbagai formulasi B. thuringiensis pada carrier limbah cair pabrik kelapa sawit (LCPKS) untuk pengendalian ulat api.

\section{BAHAN DAN METODE}

Penelitian dilakukan di Laboratorium Bioteknologi Fakultas Pertanian Universitas Muhammadiyah Yogyakarta, yang terletak di Desa Tamantirto, Kecamatan Kasihan, Kabupaten Bantul, Daerah Istimewa Yogyakart. Penelitian dilakukan pada April 2013 sampai Desember 2013.

Bahan yang digunakan antara lain adalah larva ulat api Setora nitens instar 2-3, insektisida sintetis, Dipel, nutrisi cair, limbah cair kelapa sawit, air kelapa, gula merah, air, Alkohol 75 \%, $\mathrm{pH}$, dan bakteri B. thuringiensis. Alat yang dipergunakan jarum ose, lampu Bunsen, korek api, otoklaf, Petridis, gelas beaker, tabung reaksi.

Penelitian ini terdiri dari dua tahap yaitu 
pengembangan $B$. thuringiensis pada media limbah cair pabrik kelapa sawit, dilanjutkan tahap pengujian bioassay.

Tahap satu terdiri dari 4 formulasi:

A. LCPKS $100 \%+0,4$ g gula merah $+30 \mathrm{ml}$ air kelapa + B. thuringiensis

B. LCPKS $75 \%+0,4$ g gula merah $+30 \mathrm{ml}$ air kelapa + B. thuringiensis

C. LCPKS $50 \%+0,4$ g gula merah $+30 \mathrm{ml}$ air kelapa + B. thuringiensis

D. Media Luria Bertani Cair + B. thuringiensis

Perlakuan diulang sebanyak 3 kali, pengamatan dilakukan terhadap jumlah bakteri $B$. thuringiensis pada jam ke 0, 24, 48, dan 72 dengan metode Plate Count.

Tahap kedua terdiri dari 5 perlakuan yaitu:

A. LCPKS $100 \%+0,4$ g gula merah $+30 \mathrm{ml}$ air kelapa + B. thuringiensis

B. LCPKS 75\% + 0,4 g gula merah $+30 \mathrm{ml}$ air kelapa $+B$. thuringiensis

C. LCPKS $50 \%+0,4$ g gula merah $+30 \mathrm{ml}$ air kelapa + B. thuringiensis

D. Media Luria Bertani Cair + B. thuringiensis konsentrasi 11,4\%.

E. Kontrol dengan menggunakan air

Penelitian ini disusun Rancangan Acak Lengkap dengan rancangan percobaan faktor tunggal dengan 5 perlakuan masing-masing perlakuan 3 kali ulangan dengan lima sampel ulat api, sehingga total ada $5 \times 3 \times 5=45$ ulat api. Parameter tahap satu yaitu penghitungan jumlah bakteri $B$. thuringiensis, dengan menghitung jumlah bakteri dengan satuan Colony Forming Unit Per Milliliter $(\mathrm{CFU} / \mathrm{ml})$. Parameter tahap dua yaitu parameter yang diamati adalah mortalitas (\%), kecepatan kematian (ekor/hari), perubahan persentase populasi (\%) dan hambatan makan (\%).
Data penelitian tahap 1 yakni jumlah bakteri dimasukkan dalam tabel dan dibuat grafik untuk analisisnya. Sedangkan tahap 2 yakni mortalitas, perubahan persentase populasi dan hambatan makan dimasukkan dalam tabel dan grafik lalu dilakukan pengujian dengan menggunakan analisis sidik ragam (analisis of variance), apabila ada beda nyata dilakukan uji lanjut dengan menggunakan uji DMRT (Duncan Multiple Range Test) pada taraf kesalahan $5 \%$.

\section{HASIL DAN PEMBAHASAN}

Perbanyakan B. thuringiensis pada berbagai Formulasi Limbah Cair Pabrik Kelapa Sawit

Pengembangan $B$. thuringiensis yang dimaksud adalah memberikan B. thuringiensis dalam media alternatif agar bakteri tersebut tumbuh dan berkembang sampai memproduksi spora dan kristal protein Delta Endoktoksin. Media yang digunakan sebagai media bakteri yaitu limbah cair pabrik kelapa sawit sebagai media fermentasi alternatif untuk mengembangkan $B$. thuringiensis. Kemudian di shaker selama 24, 48 dan 72 jam setelah itu dihitung koloni bakteri dengan metode plate count.

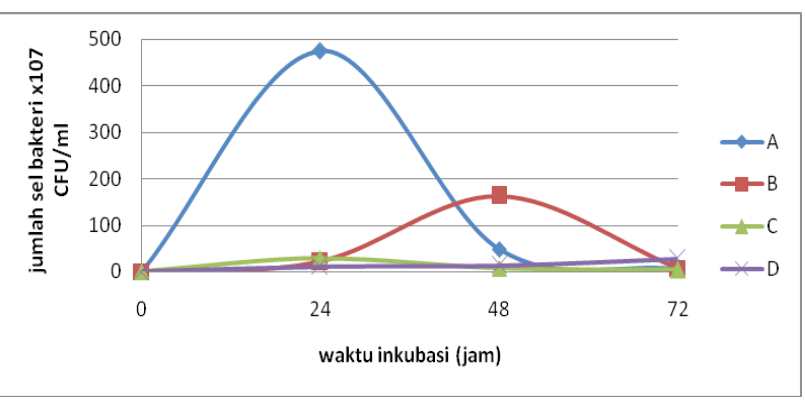

Gambar 1. Kurva pertumbuhan bakteri $B$. thuringiensis pada media LCPKS dan LBC

Keterangan:

A. LCPKS $100 \%+0,4 \mathrm{~g}$ gula merah $+30 \mathrm{ml}$ air kelapa $+B$. thuringiensis

B. LCPKS $75 \%+0,4$ g gula merah $+30 \mathrm{ml}$ air kelapa $+B$. thuringiensis

C. LCPKS $50 \%+0,4 \mathrm{~g}$ gula merah $+30 \mathrm{ml}$ air kelapa $+B$. thuringiensis D. LBC + Bacillus thuringiensis 
Kurva pertumbuhan bakteri dapat dipisahkan menjadi empat fase utama: fase lag (fase lamban atau fase lag phase), fase pertumbuhan eksponsial (fase pertumbuhan cepat atau fase $\log$ phase), fase stasioner (fase statis atau stasionary phase) dan fase penurunan populasi (decline) (Gambar 1). Fase-fase tersebut mencerminkan keadaan bakteri dalam kultur tertentu (Kusnadi et al, 2011). Hasil pengamatan menunjukkan adanya perkembangan jumlah sel bakteri yang berbeda antara media formulasi LCPKS dan media LBC. Pertumbuhan B. thuringiensis pada formulasi LCPKS 100\% +0,4 g gula merah +30 $\mathrm{ml}$ air kelapa $+B$. thuringiensis pada hari pertama memasuki fase pertumbuhan atau fase log, hal ini dikarenakan B. thuringiensis dalam starter berada dalam fase yang siap untuk memperbanyak diri. Sedangkan pada formulasi LCPKS 75\% +0,4 g gula merah $+30 \mathrm{ml}$ air kelapa $+B$. thuringiensis dan LCPKS 50\% +0,4 g gula merah $+30 \mathrm{ml}$ air kelapa $+B$. thuringiensis baru akan memasuki fase lag atau pertumbuhan sel bakteri yang lamban. perlakuan yang Luriar Bertani Cair + Bacillus thuringiensis pada hari pertama memasuki fase lag atau pertumbuhan bakterinya sangat lamban, dimungkinkan adanya perubahan $\mathrm{pH}$, dan faktor lain yang tidak diketahui akan mendesak dan mengganggu biakan, mengakibatkan penurunan kecepatan pertumbuhan (Kusnadi et. al., 2011) hal tersebut didukung oleh Afriatni (2003), fase eksponsial terjadi pada jam ke 12-48 jam inkubasi pada media fermentasi glukosa dan $\left(\mathrm{NH}_{4,2} \mathrm{SO}_{4}\right)$.

\section{Pengujian Bioassay}

Uji Bioassay bertujuan untuk mengetahui toksisitas bioinsektisida terhadap ulat api instar II-III. Parameter yang diamati pada uji Bioassay yakni mortalitas (\%), perubahan persentase populasi (\%), dan hambatan makan (\%).
Tabel 1. Rerata Mortalitas dan Kecepatan Kematian Serota nitens yang Diaplkasikan $B$. thuringiensis pada Hari ke 3

\begin{tabular}{lcc}
\hline \multicolumn{1}{c}{ Perlakuan } & Mortalitas (\%) & Kecepatan Kematian (hama/hari) \\
\hline LCPKS 100\% & 100 & 4,60 \\
LCPKS 75\% & 89 & 4,83 \\
LCPKS 50\% & 44 & 7,17 \\
Media Luriar Bertani Cair & 89 & 4,30 \\
\hline
\end{tabular}

Tabel 1 menunjukkan mortalitas pada hari ke 3 pada perlakuan LCPKS $100 \%+0,4$ g gulah merah $+30 \mathrm{ml}$ air kelapa mempunyai tingkat kematian $100 \%$. Hal ini diduga perkembangan $B$. thurngiensis pada fase eksponensial atau fase pertumbuhan cepat, sehingga dihasilkan spora delta endotoksin yang lebih banyak. Jika jumlah spora delta endotoksin yang dihasilkan lebih banyak maka daya bunuhnya akan tinggi. Dibandingkan pada perlakuan $75 \%+0,4$ g gulah merah +30 $\mathrm{ml}$ air kelapa tingkat kematian kurang dari $50 \%$ pada hari ke 3.

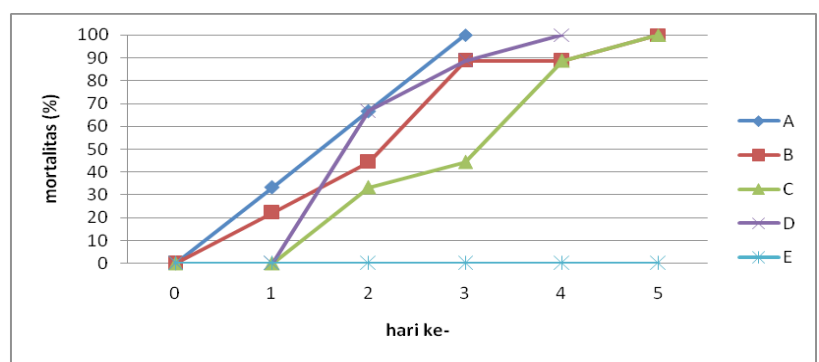

Gambar 2. Grafik Mortalitas Ulat Api pada Setiap Hari Pengamatan

Keterangan:

A. LCPKS $100 \%+0,4 \mathrm{~g}$ gula merah $+30 \mathrm{ml}$ air kelapa $+B$. thuringiensis

B. LCPKS $75 \%+0,4$ g gula merah $+30 \mathrm{ml}$ air kelapa $+B$, thuringiensis

C. LCPKS $50 \%+0,4 \mathrm{~g}$ gula merah $+30 \mathrm{ml}$ air kelapa $+B$. thuringiensis

D. $\mathrm{LBC}+$ Bacillus thuringiensis

E. Aquadest steril

Gambar 2 menunjukkan setiap perlakuan bioinsektisidal mengakibatkan mortalitas ulat api dengan peningkatan kematian yang berbedabeda. Kurva yang tertinggi dan terus menanjak yakni perlakuan LCPKS $100 \%+0,4$ g gula merah $+30 \mathrm{ml}$ air kelapa $+B$. thuringiensis pada inkubasi 48 jam dan perlakuan LCPKS 75\% + 
0,4 g gula merah $+30 \mathrm{ml}$ air kelapa $+B$. thuringiensis, menunjukkan daya bunuh sangat kuat terhadap ulat api instar II. Perlakuan LCPKS $50 \%+0,4$ g gula merah $+30 \mathrm{ml}$ air kelapa $+B$. thuringiensis dan formulasi $B$. thurngiensis murni peningkatan mortlitas mulai terjadi setelah pengamatan hari kedua. Yang disebabkan oleh pertumbuhan bakteri pada fase stasioner. Pada fase inilah spora dan protein Delta Endotoksin diproduksi. Sedangkan pada perlakuan kontrol tidak ada menunjukkan kematian sampai akhir hari pengamatan. Rerata mortalitas pada hari ke 3 tersaji pada tabel 1 .

Hasil pengamatan kecepatan kematian menunjukkan adanya pengaruh nyata perlakuan terhadap kecepatan kematian. Meskipun pada semua perlakuan tidak ada beda nyata tetapi hasil analisis pada perlakuan LCPKS 50\% + 0,4 g gula merah $+30 \mathrm{ml}$ air kelapa menunjukkan kecepatan kematian yang lama. Sedangkan pada perlakuan B. thuringiensis murni pada media LBC memiliki kecepatan kematian yang pendek. Untuk perlakuan LCPKS 100\% dan LCPKS $75 \%$ tidak menunjukkan adanya beda nyata, tetapi perlakuan LCPKS 100 \% lebih baik dalam tingkat mortalitas yakni $100 \%$ degan perubahan persentase populasi $100 \%$.

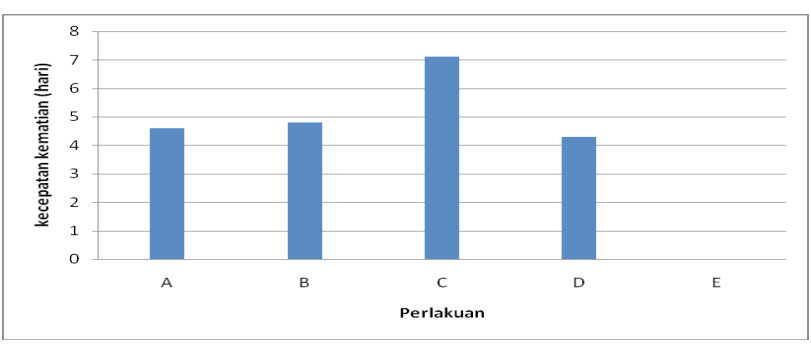

Gambar 3. Histogram Rata-Rata Kecepatan Kematian Ulat Api Selama 5 Hari Pengamatan

Keterangan:

A. LCPKS $100 \%+0,4 \mathrm{~g}$ gula merah $+30 \mathrm{ml}$ air kelapa $+B$. thuringiensis

B. LCPKS $75 \%+0,4$ g gula merah $+30 \mathrm{ml}$ air kelapa $+B$. thuringiensis

C. LCPKS $50 \%+0,4 \mathrm{~g}$ gula merah $+30 \mathrm{ml}$ air kelapa $+B$. thuringiensis

D. $\mathrm{LBC}+$ Bacillus thuringiensis

E. Aquadest steril

\section{Pada Gambar 3 kecepatan kematian setiap} hari menunjukkan setiap perlakuan bioinsektisidal mempunyai kecepatan kematian ulat api instar II dengan tingkat kecepatan yang berbedabeda. Kecepatan kematian ditunjukkan pada perlakuan media LBC + B. thuringiensis yakni 4,3 . Untuk perlakuan pada media formulasi limbah cair pabrik kelapa sawit kecepatan kematian ditunjukkan pada perlakuan LCPKS 100\%+ 0,4 g gula merah+ $30 \mathrm{ml}$ air kelapa yakni 4,6. Pada perlakuan LCPKS 50\% +0,4 g gula merah+ 30 $\mathrm{ml}$ air kelapa memiliki tingkat kecepatan kematian yang lama. Sedangkan perlakuan pada fermentasi B. thuringiensis murni dan memiliki kecepatan kematian yang rendah meskipun pada tingkat mortalitas kematian sangat tinggi. Hal tersebut diduga protein delta endotoksin digunakan dalam metabolisme bakteri pada fase $\log$ atau fase pertumbuhan koloninya.

Grafik perubahan populasi ulat api menunjukkan perubahan persentase populasi pada semua perlakuan, namun perlakuan LCPKS $100 \%+0,4$ g gula merah $+30 \mathrm{ml}$ air kelapa + B. thuringiensis dan LCPKS $75 \%+0,4$ g gula merah $+30 \mathrm{ml}$ air kelapa $+B$ thuringiensis memiliki perubahan populasi persentase yang sama baik dengan tingkat mortalitas yang mengalami penurunan populasi yang efektif dengan tingkat mortalitas yang efektif (Gambar 4). Sedangkan pada perlakuan LCPKS $50 \%++0,4$ g gula merah $+30 \mathrm{ml}$ air kelapa + B. thuringiensis dan $B$. thuringiensis murni baru mengalami penurunan populasi pada hari kedua tetapi pada hari selanjutnya mengalami kenaikan penurunan populasi ulat api. Pada perlakuan kontrol tidak ada penurunan populasi selama terakhir pengamatan. 


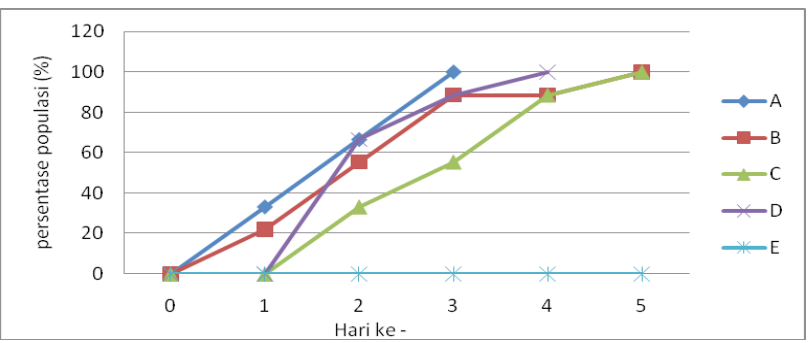

Gambar 4. Perubahan Persentase Populasi Ulat Api Selama 5 Hari

Keterangan :

A. LCPKS $100 \%+0,4 \mathrm{~g}$ gula merah $+30 \mathrm{ml}$ air kelapa + B. thuringiensis B. LCPKS $75 \%+0,4$ g gula merah $+30 \mathrm{ml}$ air kelapa $+B$. thuringiensis C. LCPKS $50 \%+0,4 \mathrm{~g}$ gula merah $+30 \mathrm{ml}$ air kelapa $+B$. thuringiensis D. $\mathrm{LBC}+$ Bacillus thuringiensis

E. Aquadest steril

Gambar 5 menunjukkan bahwa hambatan makan ulat api, aplikasi awal diberikan berat pakan yang sama, hari pertama menunjukkan penurunan berat pakan. Hal ini dikarenakan aktivitas makan masih berjalan walaupun sudah ada penurunan populasi ulat api. Aktivitas makan yang menurun pada setiap hari pengamatan pada setiap perlakuan dan diikuti penurunan populasi ulat api ini diakibatkan konsentrasi spora dan protein delta endotoksin sudah termakan oleh ulat api. Sistem pencernaan ulat api sudah diubah menjadi kristal B. thuringiensis yang protoksin menjadi polipeptida yang lebih pendek dan bersifat toksin. Bahagiawati dkk (2002) menunjukkan bahwa toksin B. thuringiensis menyebabkan terbentuknya pori-pori (lubang yang sangat kecil) di sel membran saluran pencernaan dan mengganggu keseimbangan osmotik dari sel sel tersebut, sehingga sel menjadi bengkak dan pecah hingga menyebabkan kematian ulat api. Pada perlakuan kontrol pada hari kedua dan tiga terjadi penambahan pakan, Di karenakan pakan daun kelapa sawit tidak dicelupkan insektisida, sehingga populasi ulat masih utuh ada dan aktivitas makan masih berlanjut.

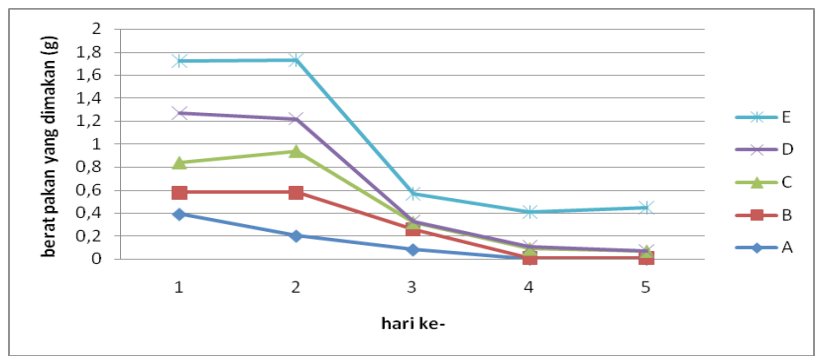

Gambar 5. Grafik Hambatan Makan Ulat Api pada Setiap Hari Pengamatan

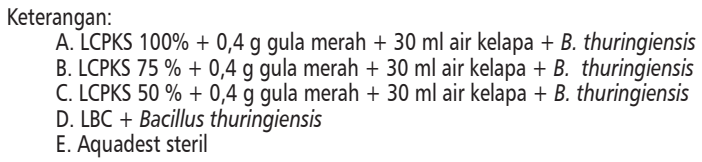

Pada hari ke-5 hambatan makan yang paling rendah ditunjukkan pada perlakuan media LBC + B. thuringiensis yakni 36,7\%. Untuk perlakuan pada media formulasi limbah cair pabrik kelapa sawit hambatan makan yang paling rendah pada perlakuan LCPKS $75 \%+0,4$ g gula merah + $30 \mathrm{ml}$ air kelapa + B. thuringiensis yakni 37,2\%. Namun dari pengamatan parameter mortalitas, kecepatan kematian dan perubahan persentase populasi masih rendah dibandingkan dengan perlakuan LCPKS 100\% + 0,4 g gula merah + 30 $\mathrm{ml}$ air kelapa $+B$. thuringiensis meskipun tingkat hambatan makan kurang rendah yakni 41,5\%.

Berdasarkan parameter mortalitas, kecepatan kematian, perubahan persentase populasi, dan hambatan makan, bioinsektisida yang dikembangkan dalam media LCPKS dan media LBC tidak berbeda nyata. Formulasi dalam bentuk media LBC lebih baik, dikarenakan bahan aktif akan lebih stabil karena kandungan vitamin dan proteinnya lebih baik sebagai pertumbuhan dan metabolisme bakteri. Dari segi ekonomi pengembangan $B$. thuringiensis pada media LBC cukup mahal, oleh karena itu dapat dipakai sebagai penggantinya digunakan media LCPKS sebagai media $B$. thuringiensis yang tersedia, selain juga 
memanfaatkan limbah yang terbuang. Dari hasil penelitian, penggunaan media LCPKS dan LBC maka menunjukkan hasil yang tidak berbeda nyata.

\section{SIMPULAN}

Media alternatif limbah cair pabrik kelapa sawit dapat digunakan sebagai media pengembangan $B$. thuringiensis. Penggunaan media alternatif LCPKS $100 \%+0,4$ g gula merah $+30 \mathrm{ml}$ air kelapa $+B$. thuringiensis memberikan hasil terbaik sebagai bioinsektisida hayati. Pada perlakuan LCPKS $100 \%+0,4$ g gula merah $+30 \mathrm{ml}$ air kelapa + B. thuringiensis karena dapat meningkatkan nilai mortalitas lebih tinggi yakni $66,6 \%$, kecepatan kematian 4,6 (hari) perubahan persentase populasi $66,6 \%$, hambatan makan $41,1 \%$.

\section{DAFTAR PUSTAKA}

Afriatni. A. 2003. Pengaruh Rasio Karbon/nitrogen (C/N) terhadap Daya Toksisitas Bioinsektisida dari Bacillus thuringiensis subsp. Kusrstaki. Fakultas Teknologi Pertanian. Institut Pertanian Bogor, Bogor.71.hal.

Bahagiawati, Rizjaani H. dan Sibuea A. K. 2009. Toksisitas Isolate Bacillus thurngiensis yang mengandung gen crylA Terhadap Hama Penggerek Batang Jagung, ostrinia furnacalis guence. Jurna biologi Indonesia 6 (1): 97-105

Ditjenbun. 2011. "ekspor produk kelapa sawit" http://ditjenbun.deptan.go.id/index.php/component/content/ article/36-news/203-ekspor-produk-kelapa-sawit-terus-naikhtml.Akses 9 Januari 2013.

Dwidjoseputro. D.1989. Dasar-Dasar Mikrobiologi.Djambatan. Malang.214.Hal.

Dwiyantores. Agung_Astuti. dan Achmad. S. 2012. Pengembangan B. thuringiensis Dalam Media Pupuk Organik Cair dan Debu Vulkanik Merapi Serta Uji Toksisitas Terhadap Ulat Grayak (Spodoptera litura) Pada Tanaman Caisim (Brassica juncea L.) Fakultas Pertanian Universitas Muhammadiyah Yogyakarta. (tidak dipublikasikan).

Kusnadi. P, Ammi, S. Widi, P. dan Dianna, R. 2011. Mikrobiologi. http://file,upi.edu/browse.php?dir+direktori/FPMIPA/JUR.PEND. BIOLOGI/96805091994031-KUSNADI/BUKU COMMON TEXT MIKROBIOLOGI\%2C Kusnadi\%2Cdkk/. diakses 3 Oktober 2013 Loekito, H. 2002. Teknologi Pengolahan Limbah Industri Kelapa Sawit. Jurnal Teknologi Lingkungan, 3 (3);242-250.

Sipayung. A. dan C.H., Hutauruk, 1982. Peningkatan Ulat Api pada Kelapa Sawit. Pedoman Teknis. Pusat Penelitian Marinhat.56 hal. 